\title{
The Influence of Ethnic Media Online on Vietnamese American Immigrant Voting Patterns
}

\author{
Judy Nguyen ${ }^{1}$ and Robin Solomon ${ }^{1 \#}$ \\ ${ }^{1}$ Leonardtown High School, Leonardtown, MD, USA \\ \#Advisor
}

ABSTRACT

Several studies have found that Vietnamese Americans display Republican voting patterns in U.S. elections compared to Democratic voting patterns found in other Asian American ethnic groups. The literature in the field speculated that these voting patterns can be explained by cultural beliefs attained from the Vietnam War and disdain for communism and China. Other research has explored the prevalence of ethnic media usage in the Vietnamese American community. This study aimed to explore the role of ethnic media usage on Vietnamese American immigrant voting patterns. To investigate this phenomenon, semi-structured qualitative interviews were conducted with six Vietnamese American immigrants ranging from the ages of 30 to 54 . The collected data was analyzed by coding for themes (thematic analysis). Analysis of the interview responses demonstrated that ethnic media usage has a significant impact on voting patterns and political beliefs. The findings of this research indicate that Vietnamese Americans sought out ethnic media that would specifically cater to their pre-existing beliefs, solidifying their political views, and ultimately leading them to vote a certain way. With this understanding, future election campaigns should focus their efforts online through ethnic media outlets to better interact with the Vietnamese community. Further research is needed to explore this phenomenon in other ethnic groups and to ascertain the importance of ethnic media to immigrant populations.

\section{Introduction}

The Vietnamese Diaspora is largely concentrated in the United States due to circumstances surrounding the Vietnam War and Vietnamese refugees seeking asylum in the United States. Diaspora is a term used to describe any group of people who have dispersed outside of their homeland and are currently residing elsewhere. There are approximately 2 million Vietnamese immigrants currently residing in the United States. This immigrant population has doubled every decade between 1980 and 2000, with an increase of 26\% since then. The United States is the top immigration destination for Vietnamese people, due to plentiful economic opportunities and guaranteed civil liberties, followed by Australia, Canada, and France (Alperin and Batalova 2018). Vietnamese Americans reside in all fifty U.S. states, but according to the 2010 U.S. Census Report, the most concentrated populations live in California, Texas, Washington, Florida, Virginia, and Georgia (Nguyen 2011).

The first wave of Vietnamese immigrants to the United States in the 1970s was conservative due to their views from escaping the Communist Regime of North Vietnam during the Vietnam War. Many of these immigrants, who are above the age of 50, have remained loyal conservatives to this day. These voters initially aligned themselves with the Republican party because of its conservative views and supported Ronald Reagan due to his staunch stance on communism (Vu 2020). The Vietnamese American voter bloc is still largely in support of the Grand Old Party (GOP) as most Vietnamese Americans support President Donald Trump: 64\% reported approving, 32\% reported disproving, and 2\% reported not knowing (AAPI Data and APIA Vote 2018). This survey by the Asian American Pacific Islander Data Institute also noted that Vietnamese Americans were the only Asian American subgroup to display majority Republican support in contrast to Chinese, Korean, Japanese, Filipino, and Indian Americans. 
Even with this major schism in the Asian community, the Asian American and Pacific Islander (AAPI) voting bloc is often referred to as a monolithic entity in U.S. media. A monolithic entity refers to a demographic that is often considered as one consolidated group of people. This is troublesome because Asian Americans consist of numerous different ethnicities that come from diverse cultural and historical backgrounds. The concept of pan-ethnicization of Asians in America ignores the inherent variances between each ethnic group such as religion, socio-economic status, culture, language, native home regimes, level of English fluency, etc. (Huang 2017). Pan-ethnicity is a newly coined expression used to group similar ethnicities together based on perceived similarities. Therefore, many Asian Americans are usually lumped together in politics, culture, and identity when usually, different ethnic groups have their own defining and dividing characteristics. Not all Asian Americans are majority Democratic as seen with Vietnamese Americans.

Unlike other Asian ethnic groups (Chinese, Koreans, Japanese, Filipino, and Indians), Vietnamese Americans demonstrate a strong affiliation with the GOP and Donald Trump rather than being democratic voters (AAPI Data and APIA Vote 2018). Certain ethnic groups such as Vietnamese Americans, need to be studied more in-depth and need to be recognized as separate entities due to their immense differences. Generalizing about these groups and further perpetuating a monolithic identity would just be inaccurate.

Vietnamese Americans have historically supported the Republican Party but the reasons why these voting patterns are still being perpetuated in the newest election cycle needs to be explored further through the lens of ethnic media consumption. Numerous sources have postulated that a cause for these voting patterns is existing cultural beliefs. With the emergence of ethnic media usage, the role of ethnic media might have changing dynamics on this community and their political beliefs.

The scope of this research was managed by targeting Vietnamese American immigrants in Southern Maryland due to the availability of this community to the researcher. Vietnamese Americans across the United States stay connected through their social groups and social media. It cannot be said that all these people share the same viewpoints, but this community is very tight knit. Even among the community, there are widespread differences such as upbringing in the United States versus Vietnam. Those inherent cultural and societal differences can have an impact on political views especially in comparison with those who have strong national pride towards Vietnam and disdain for China. The focus of this research project is on Vietnamese Immigrants to have a collective understanding of the research participants.

\section{Literature Review}

The AAPI population is the fastest-growing demographic group in the United States including those who are Vietnamese Americans (Nakanishi 2001, AAPI Data and APIA Vote 2018, Yam 2020). The Asian American electorate has grown 130\% in the past 20 years, and this can have many implications in future elections (Yam 2020). With consistent population growth, increased voter registration, and turnout, the Asian American demographic is becoming a formidable force in elections. Having reliable data and knowledge of these groups is crucial to electoral predictions and campaigning strategies. Many Vietnamese immigrants become U.S. Citizens (naturalized) every year and with that comes their right to vote in any U.S. election. These Vietnamese American voters often reside in battleground states where their vote could have a significant impact depending on close margins (Vu 2020, Huang 2017, Satzewich 2020, Kandil 2018).

One speculation behind Vietnamese American voting patterns is due to cultural beliefs. The Vietnamese American community is bonded in their mutual dislike of communism and many of these voters admire President Donald Trump for the anti-China rhetoric used in his speeches. Historically, there has always been a great dislike of China within Vietnamese populations, but their relations have gotten worse since the Cold War and Vietnam War. There is a connection between the Vietnam War struggle and China's colonization of Vietnam. Therefore, many Vietnamese Americans display strong hatred towards China or choose to continue perpetuating the Vietnam-China 
rivalry. Voting in U.S elections based on homeland political struggles has been given a new name: "Diaspora politics" (Satzewich 2020). Researcher Victor Satzewich from McMaster University says that "the Vietnamese diaspora, particularly those who were part of the first wave of immigration to the United States, may believe that Trump's China policies serve their interests in the homeland. But focusing on this issue alone means they ignore other aspects of the president's domestic and foreign policy agendas" (Satzewich 2020).

The study titled "Ethnic Media in America: Hidden Giant in Plain Sight" is the dominant source in the field of ethnic media in the United States. Ethnic media is a term used to describe media that is created for a specific ethnic group usually written in their native language. This study was conducted in 2005, after the emergence and advancements of many ethnic media outlets to mainstream media. It was the first study of its kind to collect data on ethnic media usage among Ethnic Americans. The major findings of this study include that 13 percent of the American adult population (29 million people) prefer ethnic media to mainstream media. Of this statistic, a fourth of Asian Americans report preferring Ethnic media to its mainstream counterparts. More than half of all Vietnamese adults read an ethnic newspaper on a regular basis (Center for American Progress 2005). With such strong statistics about the ethnic media usage in the Asian American community, specifically the Vietnamese American subgroup, there might be a direct relationship between ethnic media usage and that group's political beliefs.

Numerous articles have been released highlighting how ethnic (social) media influences Vietnamese American political beliefs. Such as in Terry Nguyen's article for Vox News titled "Support for Trump Is Tearing Apart Vietnamese American Families." The writer briefly mentions that the media consumption of Vietnamese parents is heavily reliant on ethnic media such as BBC Vietnam and Voice of America Tiếng Việt. There is a strong possibility that ethnic media has a considerable influence on the Vietnamese American community, specifically, on their political beliefs that have yet to be thoroughly explored. The consumption of available media is one of the main agents of political socialization, supporting a relationship between ethnic media and political beliefs.

There are trends in the decline of support of the Republican Party among younger Vietnamese voters. One speculation behind this trend is that younger voters are typically less concerned with Cold War politics and are more interested in domestic policies and issues. Older working-class Vietnamese voters still display overwhelming support of the Republican party ( $\mathrm{Vu} 2020$ ). Younger Vietnamese voters are typically those who were born and raised in the United States, creating an entirely different political identity for these voters. The generational, educational, and cultural differences between young people and their older counterparts typically manifest into different political ideologies and identities. It is no surprise that young Vietnamese voters are typically more democratic which aligns with general voting patterns in the United States (Younger people are more likely to vote democratic in the U.S.).

The literature I have reviewed is all in discussion with one another in numerous ways, mostly concerning the cultural influences on Vietnamese American political beliefs and the emergence of ethnic media usage in this community. These commonalities are all possible identifying factors to why Vietnamese Americans are more likely to vote Republican, however, these voting patterns need to be further explored to find the connection between current ethnic media usage and how it influences political beliefs. This research project explored the question of: "To what extent are Vietnamese American Voting Patterns influenced by ethnic media online?"

\section{Methodology}

This research project, aimed at fully understanding the relationship between ethnic media usage and Vietnamese American Immigrant voting patterns, was conducted with the research approaches of phenomenology and case study research. Phenomenology is a research method used to identify certain phenomena and how it is perceived by those sharing a common experience. "Case studies are in-depth investigations of a single person, group, event, or community" (McLeod 2019). Case studies are typically used in the social sciences, such as political science, as it is appropriate when examining a real-life phenomenon/process in greater depth. Understanding how groups of people interact in their environment (a non-native country) and analyzing their political activity and behavior is directly connected to the study of political science. For this study, the identified phenomenon is that Vietnamese Americans are more likely to vote Republican than any other Asian American ethnic group.

To effectively answer my question, I had to generate qualitative data. Qualitative data is meant for phenomena that cannot be strictly represented with numerical values but instead with descriptive values. Using a combination 
of phenomenology and case study research, I gained a holistic view of the phenomenon and generated generalizable results allowing for research replication.

The research collection process first began by receiving approval from the Institutional Review Board (IRB) allowing me to conduct my research. I conducted semi-structured qualitative interviews with six Vietnamese immigrants. Semi-structured interviews are preferred when using a phenomenological and case study approach because it allows flexibility in responses but still covers the same areas of data collection (Noor 2008).

For the interviews, I asked each participant the same set of definitive questions. The use of definitive questions allowed for anecdotal responses without any pretense of guided answers.

Each interview was allotted a maximum time limit of one hour to ensure each participant was given a fair amount of time. Within this time frame, each participant was asked the same eleven questions. The first five questions were simple identification questions used to guarantee that the participants met the sampling criteria. The last six questions were written in a way that would prompt anecdotal responses and explore the participant's political identity. Below is a table containing the interview questions used in the semi-structured qualitative interviews.

Table 1. Semi-Structured Qualitative Interview Questions

\begin{tabular}{|l|}
\hline How old are you? \\
\hline Are you a naturalized U.S. citizen? \\
\hline How long have you resided in the United States? \\
\hline At what age did you leave Vietnam? \\
\hline Do you live in Maryland? If so, which county? \\
\hline Describe your ethnic media usage. How often do you use it? Do you prefer social media or proper news outlets? \\
\hline Where do you primarily get your political news or information from? \\
\hline $\begin{array}{l}\text { Who did you vote for in the } 2020 \text { Presidential Election? How did you vote in previous presidential elections, please } \\
\text { describe all instances in which you have voted prior? }\end{array}$ \\
\hline What political issues do you find of most concern/are most important to you? \\
\hline $\begin{array}{l}\text { Describe how you have developed your political identity/affiliation. What has influenced you the most in this } 2020 \\
\text { election cycle? }\end{array}$ \\
\hline $\begin{array}{l}\text { What political party are you registered to vote for? Describe your understanding of the two major U.S. Political } \\
\text { Parties (Democrats and Republicans). }\end{array}$ \\
\hline
\end{tabular}

(See Appendix 1 for the interview questions in Vietnamese)

Using purposive sampling, I selected participants for my study based on IRB-approved requirements that would generate relevant data to answer the research question. Khairul Noor says that purposive sampling is a great sampling strategy as the researcher produces a sample that is assumed to be representative of the population due to prior investigation and logic. With this in mind, I created the sampling criteria and sought out individuals that met this criterion.

This study's participation requirements are as follows: a naturalized U.S. citizen of Vietnamese descent (a Vietnamese Immigrant) residing in Southern Maryland and is 30 or older with no basis on gender. The sampling criteria allowed me to identify participants whose experiences were relevant to the study and pertained to the phenomena.

I recruited participants for my research through familial contacts. I heavily relied on a female Vietnamese Immigrant who was well connected with other Vietnamese immigrants in the Southern Maryland community. I met with individual participants at their homes and their places of work and conducted face-to-face interviews within the Center for Disease Control (CDC) guidelines to ensure safety between myself and the participants, as the COVID-19 Pandemic was still ongoing during my data collection process. Potential participants were given an Informed Consent Form in person and those who agreed to the terms were then interviewed. 
Some of the participants that were recruited were not fluent in English, and as a result, these interviews were conducted in Vietnamese and partially in English. I gave each of the participants a copy of the questions in Vietnamese and English and used my proficiency as a Vietnamese speaker to transcribe the responses to the best of my ability and to ensure that the responses were communicated as intended. The interviews were recorded on a cellular device using the Voice Memos application and then were later transcribed into a document. None of the participants' names were recorded in order to ensure anonymity and confidentiality.

This study paired an interpretivist research paradigm with thematic analysis to fully analyze and understand the collected data. I examined the interview data through an interpretivist research paradigm, the idea that there is not a single truth but different interpreted meanings. This qualitative method focuses on the why and how of a certain phenomenon instead of the what, where, and when. This is also better suited for smaller, focused sample populations instead of larger sample populations (Nichols et al 2019).

The interpretivist research paradigm is characterized through observation and interpretation. Observation is simply defined as collecting information. For my research, this was accomplished through interviewing participants and recording their responses. Interpretation is simply defined as giving meaning to information by creating patterns and possible inferences from the data. Patterns were created by initially identifying what themes were found throughout the participant's responses. These themes were then further examined by finding similarities between the participants' responses. I inferred more about the participants' backgrounds and answers by connecting similar responses. Additional patterns were created by the frequency of topics and themes found in the interview data. Common ideas that were expressed numerous times throughout each of the individual participants' responses were connected back to the existing literature in the field. For example, the topic of China came up several times in the interviews. The high frequency of these types of responses made sense due to the established cultural knowledge of this ethnic group. This paradigm is meant to expand the understanding of the research group by exploring the experiences of the individuals. There is an emphasis on exploring the subjective viewpoint rather than an objective viewpoint even existing.

For thematic analysis, I identified central themes from the participants' responses by first establishing concepts. These concepts were created prior to examining the participant's responses. They were created based on the topic areas that were covered by the interview questions. Themes were then created by examining the participant's responses and summarizing the main ideas of the interview data. Similar to the interpretivist research paradigm, I created patterns by examining the frequency of themes and data points. I then connected them to the established phenomena to better define the connection between ethnic media usage and Vietnamese American Immigrant voting patterns.

\section{Results}

The questions asked in the semi-structured qualitative interview were structured around three main concepts: (1) Vietnamese American Immigrants' political identity through political socialization of media, (2) Vietnamese American Immigrants' perception of current political affairs, (3) and the cultural impact of being Vietnamese American on political views. From these concepts, three main themes were identified from the interview responses. These identified themes and their explanations are listed in the table below.

Table 2. Identified Themes and Explanations

\begin{tabular}{|l|l|}
\hline Theme & Explanation \\
\hline $\begin{array}{l}\text { 1. Vietnamese American Immigrants' rela- } \\
\text { tionship with ethnic media and other media } \\
\text { sources }\end{array}$ & $\begin{array}{l}\text { Relates to the usage and prevalence of ethnic media within the daily } \\
\text { lives of Vietnamese Immigrants. Includes other news sources that Vi- } \\
\text { etnamese Immigrants consume that are not necessarily for Viet-spe- } \\
\text { cific audiences. }\end{array}$ \\
\hline
\end{tabular}




\begin{tabular}{|l|l|}
\hline $\begin{array}{l}\text { 2. Vietnamese American Immigrants' } \\
\text { shared beliefs within an ethnic cluster/so- } \\
\text { cial community }\end{array}$ & $\begin{array}{l}\text { Relates to the influence of living in a social community and the shared } \\
\text { beliefs of those who participate together socially. Pertains to how in- } \\
\text { formation is shared and what is being shared between members of the } \\
\text { community. }\end{array}$ \\
\hline $\begin{array}{l}\text { 3. Vietnamese American Immigrants' } \\
\text { identification of politically related subjects }\end{array}$ & $\begin{array}{l}\text { Relates to the identification and acknowledgment of current political } \\
\text { issues in the United States and how they view these issues. Includes } \\
\text { how Vietnamese Immigrants perceive different political parties. }\end{array}$ \\
\hline
\end{tabular}

Each of these themes can be identified among all the interview responses but this does not necessarily mean that all three can be found in each individual response. In the following table, Table 3, there is a summary of each participant's responses to the interview, including the theme(s) that were identified in their responses.

Table 3. Summary of Semi-Structured Qualitative Interviews and Identified Theme(s)

\begin{tabular}{|c|c|c|}
\hline Participant & Summary of Interview & $\begin{array}{l}\text { Identified } \\
\text { Theme(s) }\end{array}$ \\
\hline Participant 1 & $\begin{array}{l}\text { The participant is currently a naturalized U.S. citizen, has resided in the U.S. for } \\
\text { almost } 30 \text { years, and is currently living in St. Mary's County, Maryland. The } \\
\text { participant is } 48 \text { years old and left Vietnam at the age of 12. Participant prefers } \\
\text { watching American news outlets and media sources such as CNN, Fox News, } \\
\text { MSNBC, NBC, and other internet outlets. He rarely engages with ethnic media } \\
\text { but describes his media usage as frequent, every day for about } 1 \text { to } 2 \text { hours. He } \\
\text { is a lifetime registered Republican, voting for Republican Presidential Candi- } \\
\text { dates such as Bush, McCain, Romney, and Trump. His issues of most concern } \\
\text { are the economy and illegal immigration. He states that watching the news and } \\
\text { the current state of the economy has influenced him the most during the } 2020 \\
\text { Presidential Election Cycle. He described Republicans as caring more for the } \\
\text { country and economy while Democrats were bringing in too many illegal immi- } \\
\text { grants; the participant was not entirely too confident in describing the difference } \\
\text { between the political parties. }\end{array}$ & 1,3 \\
\hline Participant 2 & $\begin{array}{l}\text { The participant is currently a naturalized U.S. citizen, has resided in the U.S. for } \\
\text { almost } 28 \text { years, and is currently living in Charles County, Maryland. The par- } \\
\text { ticipant is } 54 \text { years old and left Vietnam at the age of } 25 \text {. The participant watches } \\
\text { both ethnic media and American news outlets and does not have a preference } \\
\text { over the other. She describes her ethnic media usage as very frequent, every day } \\
\text { for about } 3 \text { to } 4 \text { hours. She primarily gets her political information from Viet- } \\
\text { namese conservative YouTubers. Participant states that she discusses her beliefs } \\
\text { with her friends, families, and co-workers very often online and in person. She } \\
\text { is a lifetime registered Republican, voting for Republican Presidential Candi- } \\
\text { dates such as Bush, McCain, Romney, and Trump. She states that watching the } \\
\text { news and the prevalence of fake news has influenced her the most during the }\end{array}$ & $1,2,3$ \\
\hline
\end{tabular}




\begin{tabular}{|c|c|c|}
\hline & $\begin{array}{l}2020 \text { Presidential Election Cycle, especially influencing her to see issues in a } \\
\text { different light. Her issues of most concern were the economy, China and pre- } \\
\text { venting the spread of Communism, and maintaining American dominance } \\
\text { through the military. She described Republicans as honest and having the peo- } \\
\text { ple's interest in mind while Democrats are corrupt and controversial in instances } \\
\text { such as Hillary's emails and Benghazi. She also describes Democratic leader- } \\
\text { ship as not strong enough to hold up against foreign powers such as North Korea } \\
\text { and China. Participant likes that Republicans are considered traditional and old- } \\
\text { fashioned. }\end{array}$ & \\
\hline Participant 3 & $\begin{array}{l}\text { The participant is currently a naturalized U.S. citizen, has resided in the U.S. for } \\
\text { almost } 16 \text { years, and is currently living in St. Mary's County, Maryland. The } \\
\text { participant is } 45 \text { years old and left Vietnam at the age of } 29 \text {. The participant } \\
\text { rarely watches the news in her free time but gets most of her information through } \\
\text { word of mouth from family, friends, and co-workers. She states that these people } \\
\text { primarily get their information from ethnic media sources online. However, she } \\
\text { does obtain some political information from the Internet, Facebook, and } \\
\text { YouTube. The participant has voted once in their lifetime, voting for Trump in } \\
\text { the } 2020 \text { U.S. Presidential Election. Her issues of most concerns were the econ- } \\
\text { omy, preventing the spread of Communism, and China. She does not have a } \\
\text { strong political identity but says that she was most influenced by her community } \\
\text { and those in her social circle. The participant could not identify the differences } \\
\text { between the two major U.S. Political Parties but could identify the candidates } \\
\text { from each party; she favors the Republican Party because Donald Trump is a } \\
\text { Republican. She is not registered for any political party. }\end{array}$ & $1,2,3$ \\
\hline Participant 4 & $\begin{array}{l}\text { The participant is currently a naturalized U.S. citizen, has resided in the U.S. for } \\
\text { almost } 17 \text { years, and is currently living in St. Mary's County, Maryland. The } \\
\text { participant is } 39 \text { years old and left Vietnam at the age of } 23 \text {. The participant } \\
\text { mostly consumes ethnic media. She describes her ethnic media usage as very } \\
\text { frequent, every day for about } 1 \text { to } 2 \text { hours. She primarily receives her political } \\
\text { information from Facebook and Vietnamese conservative YouTubers. She fre- } \\
\text { quently discusses politics with her family, friends, and co-workers whom she } \\
\text { shares many of her views. The participant has voted once in their lifetime, voting } \\
\text { for Trump in the } 2020 \text { U.S. Presidential Election. Her issues of most concern } \\
\text { were the economy, increasing legal immigration, healthcare, preventing the } \\
\text { spread of Communism, and China. The participant says that she mostly voted } \\
\text { for Trump based on his anti-China stances and because of her strong dislike for } \\
\text { China on Vietnam's behalf. She is a registered Republican. She described Re- } \\
\text { publicans as caring for the economy and small businesses; Democrats care for } \\
\text { disenfranchised groups and lower-income people but since she is a small busi- } \\
\text { ness owner, she prefers paying fewer taxes. The participant said that she did not } \\
\text { know much about the difference between the two parties other than what she } \\
\text { already stated. }\end{array}$ & $1,2,3$ \\
\hline Participant 5 & $\begin{array}{l}\text { The participant is currently a naturalized U.S. citizen, has resided in the U.S. for } \\
\text { almost } 18 \text { years, and is currently living in St. Mary's County, Maryland. The } \\
\text { participant is } 38 \text { years old and left Vietnam at the age of } 20 \text {. The participant } \\
\text { prefers ethnic media; describes ethnic media usage as very frequent, every day } \\
\text { for about } 2 \text { to } 3 \text { hours. He primarily receives his political information from }\end{array}$ & $1,2,3$ \\
\hline
\end{tabular}




\begin{tabular}{|c|c|c|}
\hline & $\begin{array}{l}\text { YouTube, Fox News, Vietnam Express-News, and other Vietnamese online } \\
\text { newspapers. The participant has voted once in their lifetime, voting for Trump } \\
\text { in the } 2020 \text { U.S. Presidential Election. His issues of most concern were the econ- } \\
\text { omy, the COVID-19 Pandemic, preventing the spread of Communism, and } \\
\text { China. He states that watching the news and the state of the country due to } \\
\text { COVID-19 has influenced him the most during the } 2020 \text { Presidential Election } \\
\text { Cycle. He is a registered Republican. The participant described Republicans as } \\
\text { patriotic using the "America First" rhetoric used by Donald Trump. He believes } \\
\text { that Trump/Republican policies are good for the United States while Democratic } \\
\text { policies are a detriment because they cater to foreign powers. }\end{array}$ & \\
\hline Participant 6 & $\begin{array}{l}\text { The participant is currently a naturalized U.S. citizen, has resided in the U.S. for } \\
\text { almost } 15 \text { years, and is currently living in St. Mary's County, Maryland. The } \\
\text { participant is } 30 \text { years old and left Vietnam at the age of } 15 \text {. The participant } \\
\text { watches both ethnic media and American news outlets and does not have a pref- } \\
\text { erence over the other. She describes her ethnic media usage as very frequent, } \\
\text { every day for about } 2 \text { to } 3 \text { hours. She primarily receives her political information } \\
\text { from YouTube, Fox News, CNN, ABC News, Yahoo News, and Facebook. The } \\
\text { participant has voted once in their lifetime, voting for Trump in the } 2020 \text { U.S. } \\
\text { Presidential Election. Her issues of most concern were the economy, the War } \\
\text { on Terror (Iraq War), preventing the spread of Communism, and China. She } \\
\text { states that she is an independent voter that votes based on whatever policies she } \\
\text { likes better. The participant describes Republicans as the party that boosts the } \\
\text { economy and creates more jobs. She believes that Republicans encourage peo- } \\
\text { ple to "pull themselves up by the boot-straps" while Democrats promote social } \\
\text { programs such as EBT and Welfare which encourages people to be lazier. }\end{array}$ & $1,2,3$ \\
\hline
\end{tabular}

The contents of Table 3 summarize each of the interviews into the main ideas and takeaways from the participant's responses to the questions. All but one of the participants' responses displayed all three themes indicating that none of the interview data was that drastically different from one another. By identifying these three themes after assessing the data, I was able to find a connection between ethnic media usage, a sense of cultural community, perception of politics based on shared cultural beliefs, and Vietnamese American voting patterns.

\section{Analysis}

\section{Theme 1: Vietnamese American Immigrants' Relationship with Ethnic Media and Other}

The basis of my research project was to identify the political influence that ethnic media had on Vietnamese Americans; Theme 1, as described in Table 2, succinctly expresses what I was exploring in my research. The relationship between ethnic media and Vietnamese Americans' political views was largely unexplored by previous research in the field. However, there was a lot of data to suggest reasoning for Vietnamese American's Republican voting patterns such as cultural beliefs. My research was aimed to further explore the phenomenon solely through the focus of ethnic media.

Of the six interviews, all six participants' responses included information relating to Theme 1. Four out of the six interviewees described their ethnic media usage as frequent and the average amount of media time for all the participants based on the median is 2 to 3 hours. 
One of the interviewees, Participant 3 from Table 3, did not consume ethnic media directly but said that she received most of her political information from her family, friends, and co-workers; She specifically states that these people get their information from ethnic media. This indirect relationship between ethnic media usage and this participant still manifests itself in her life to influence her political decisions.

Participant 1 from Table 3 was the outlier of the group and was the only person to not have some ethnic media influence; he was the only person who primarily consumed American news outlets. Nonetheless, he still voted the same way as the rest of the group, and this could be due to his cultural beliefs that are also aligned with the rest of the interviewees. This participant was the only person to have conducted his entire interview in English, suggesting that there are other fundamental differences between him and the rest of the interviewees. He does not have to rely on ethnic media, due to fluency in English, to understand the current state of affairs. These findings do suggest that ethnic media has a considerable influence on Vietnamese American voting patterns due to the strong connection between frequent usage and voting Republican.

\section{Theme 2: Shared Beliefs Within an Ethnic Cluster/Social Community}

Theme 2, as described in Table 2, focuses directly on the influence of living in a social community and the shared beliefs of those who participate together socially and culturally. The correlation between Vietnamese cultural beliefs and voting patterns was identified and established in prior research in the field. However, these beliefs were not explored through the focus of ethnic media and whether ethnic media upheld these beliefs.

Of the six interviews, five out of the six participants' responses included information relating to Theme 2 . Five out of the six participants were able to attribute aspects of their political socialization to cultural beliefs/upbringing and other institutions such as friends and families, excluding media as this was discussed in the previous theme. Participant 1 from Table 2 was the only participant to not have Theme 2 show up in his data set. As stated earlier, Participant 1 was the only person to conduct his interview in English as he was fully proficient in the language, suggesting that there might be some form of cultural detachment towards those who are more Americanized, a term used to describe the level of American cultural assimilation. The other five participants all displayed strong ethnic media usage and expressed similar thoughts/beliefs during their interviews.

All six of the participants expressed very strongly that their issues of most concern included the economy, not only that, but all the participants described it as their top issue. This belief can be commonly found in immigrant populations because most immigrants seek new lives to better their financial situations and to find better employment. It can be presumed that the interviewees obtain information pertaining to the U.S. economy through their media of choice, such as ethnic media.

Five out of the six participants identified China or the prevention of the spread of Communism as one of their key issues of concern. The understanding of Vietnamese Americans' dislike of China and communism was established previously in the literature review by current information in this field. My research further upholds this understanding and strengthens the already-established relationship between Vietnamese Americans and voting based on home-land interests or "Diaspora politics."

Three out of the six participants which represent half of the sampling population explicitly described that their family, friends, and co-workers had a considerable influence on their beliefs. Existing in a cultural bubble that regularly interacts with one another can have a significant impact on things such as political views. This environment shuts out opposing viewpoints because people only interact and encounter others with similar beliefs, successfully creating an echo chamber. This term is often used in news media to refer to situations where existing beliefs thrive in a closed system. 


\section{Theme 3: Identification of Politically Related Subjects by Vietnamese Americans}

Theme 2 relates directly to the presence of shared beliefs in an ethnic cluster/social community while Theme 3, as described in Table 2, relates to how Vietnamese Americans perceive politically related subjects such as wedge issues and political parties. A wedge issue is a term used to refer to divisive social or political issues. The phenomenon identified in this research project was that Vietnamese Americans are more likely to vote Republican than any other Asian ethnic group. With this understanding, it is reasonable to conclude that Vietnamese Americans hold conservative views on many political issues.

Of the six interviews, all six participants voted Republican, four of the six were registered Republicans while the other two were registered as Independent. Five out of the six participants were able to explicitly express their support towards conservative policies and were able to differentiate the two political parties to some degree while one participant was not able to. Participant 2 from Table 2 was unable to identify the differences between the two major U.S. Political Parties but could identify the candidates from each party. Additionally, she did state that she favored the Republican party solely because it is the party of Donald Trump. Participant 2 was also part of the group of two participants who were registered as Independent.

Three out of the six participants which represent half of the sampling population described the Democratic party as more socially oriented, than the Republican party by explaining that Democrats are more concerned with (maintaining) illegal immigration, increasing taxes, and expanding social programs like Welfare and EBT.

Five out of the six participants perceived the Democratic party negatively, one participant remained neutral, however, all six participants perceived the Republican party positively. Some of these positive sentiments included: caring for the country and wellbeing of American citizens (America First), honesty, understanding for small business owners, encouraging hard work, and a strong global presence towards foreign powers (North Korea and China).

The way Vietnamese American Immigrants perceive politics in the United States can be boiled down to a two-fold relationship that incorporates ethnic media and living in an ethnic cluster/social community. Prolonged exposure to similar cultural beliefs will reinforce these ideas causing one to seek information that will only uphold these pre-existing beliefs. Such is the case with the participants and other Vietnamese American Immigrants. Living in these social communities with a lack of close interaction with outsiders will only strengthen these ideas and seeking information online that aligns with these ideas will just further the cycle.

\section{Implications}

The importance of my research stems from the growth of the Asian American and Pacific Islander population. This demographic is consistently found to be the fastest-growing group in the United States (Nakanishi 2001, AAPI Data and APIA Vote 2018, Yam 2020). A drastic increase in these voter populations can lead to changes in voting and election dynamics. These changes can be attributed to consistent population growth, increased voter registration, and turnout. Accompanying these dynamic changes is the increased impact of the Asian American vote. Many Vietnamese Immigrants gain the right to vote every year and having reliable data and knowledge of this group is crucial to electoral predictions and campaigning strategies. These Vietnamese American communities are concentrated in battleground states where their vote could have a significant impact depending on close margins (Vu 2020, Huang 2017, Satzewich 2020, Kandil 2018). With the new understanding from my research, a necessary way to increase Vietnamese American support would be to increase political outreach online through ethnic media in future elections. 


\section{Conclusion}

The aim of my research project was to explore the role of ethnic media in Vietnamese American Immigrant voting patterns and to gain a more comprehensive understanding of the relationship between the two. I aimed to explore the phenomenon of Vietnamese Americans being more likely to vote Republican than any other Asian ethnic group and if the presence of ethnic media had any significant influence on this demographic. I intentionally narrowed the scope of my research by only interviewing Vietnamese American immigrants which specifically excludes American-born citizens of Vietnamese descent. This distinction was made to explore how the role of foreign-based media or secondary news sources impact the communities that they serve. After conducting semi-structured interviews with six different Vietnamese American immigrants, followed by thematic analysis paired with an interpretivist research paradigm, the conclusions to my research are extensive.

The relationship between ethnic media and voting patterns had not been fully explored prior, however, the relationship between cultural beliefs and voting patterns has been previously established and supported. My research findings further support the identification of immigrants voting based on homeland interests or "Diaspora politics" (Satzewich 2020).

Furthermore, the findings of my research establish a new understanding of the role of ethnic media and how it works to influence the Vietnamese American immigrant population. The responses that were given by participants suggested that the role of ethnic media is not a stand-alone factor but instead works in tandem with pre-existing cultural beliefs to influence people to vote a certain way. Ethnic media is used as a tool for Vietnamese American Immigrants to remain informed on current events but also to consume content that is palatable to them. Vietnamese American Immigrants just like many other populations are politically socialized by many institutions such as the media, family, peers, cultural upbringing, education, etc.

The way Vietnamese American Immigrants regard politics in the United States can be reduced to a twofold relationship that incorporates ethnic media and living in an ethnic cluster/social community. Vietnamese American Immigrants sought out ethnic media that would specifically cater to their pre-existing beliefs, solidifying their political views, and ultimately leading them to vote a certain way.

\section{Limitations}

During my research process, I utilized thematic analysis paired with an interpretivist research paradigm to interpret the findings of my phenomenological and case study research, so I must address any limitations I encountered during my research.

The definitive interview questions were created in hopes of gauging a better understanding of the role of ethnic media. I recruited Vietnamese American Immigrants to conduct my research. Due to the nature of my interview questions, the time constraint of an hour, and the existing language barrier, the conditions of the interview might have not been sufficient to prompt a well-articulated response from the interviewees. All the participants finished their interviews well under the time limit. This suggests that their level of understanding and their ability to form a fully developed and nuanced response was due to things outside of my control, such as their fluency of English or my fluency of Vietnamese.

The data collected from the interviews were sufficient to draw substantial conclusions and to answer my research question despite the scope of the data collection. I employed a purposive sampling strategy to recruit participants for my research. Despite the small sampling population, I was able to collect substantial data from the six participants. Nonetheless, a larger sampling population would ensure a greater representation of the target population within the results. 


\section{Future Directions}

Firstly, my research question was focused solely on the impact of ethnic media on Vietnamese American Immigrants and their political beliefs/voting patterns, but my findings and analysis suggested that cultural connections played a more significant role than I previously had thought. My research project was focused on a small population of immigrants from a rural region of the state of Maryland.

Future researchers aiming to further explore the role of ethnic media in Vietnamese American Immigrant populations should seek to continue this research in different Vietnamese communities of the United States. The research method I have developed allows for easy replication meaning that this research can be easily continued with other groups of Vietnamese American Immigrants. If necessary for the field of political science, this research method can be easily tweaked to examine the role of ethnic media in other ethnic groups across the United States or the globe. To gain a more complete scope of understanding, it is advisable that future researchers should investigate the actual content of the ethnic media sources that are being consumed by this community. Additionally, this research method should be replicated in other ethnic group communities of the United States to identify if the relationship between ethnic media and immigrants is common or if it is circumstantial to just this group of participants.

The age of my participants ranged from 30 to 54, typically in the political science discipline, these age demographics are further broken down into subsections that can be further examined for trends and relationships for voting patterns. If desirable, future researchers should replicate my research method to recruit different participants within distinct age demographics to denote different trends and relationships relating to age, ethnic media, and voting patterns.

\section{Acknowledgments}

This project would not have been possible without the support of many people. I would like to express my gratitude to my AP Research Teacher, Dr. Robin Solomon, who guided me throughout this project.

I would also like to thank my dear friends and peers for continuing to be by my side throughout this time. For staying up late nights listening to me rant and for always being available to read and edit my paper.

Thank you to my mom for having so many connections within the Vietnamese community and for supporting all of my endeavors.

Most importantly, thank you to the Journal of Student Research for supporting the academic dreams of many students, including this one, and making the world a more knowledgeable place.

\section{References}

AAPI Data and APIA Vote. 2018. “2018 Asian American Voter Survey (AAVS).” https://aapidata.com/2018survey/.

Alperin, Elijah, and Jeanne Batalova. 2018. "Vietnamese Immigrants in the United States." Migration Policy Institute. https://www.migrationpolicy.org/article/vietnamese-immigrants-united-states-5.

Center for American Progress. "Ethnic Media in America: Hidden Giant in Plain Sight." Center for American Progress. Last modified June 29, 2005. https://www.americanprogress.org/events/2005/06/30/16308/ethnic-media-in-america/. 
Evans, Ceryn. Analysing Semi-Structured Interviews Using Thematic Analysis: Exploring Voluntary Civic Participation Among Adults. Edited by Lewis, Jamie, ed55 City Road, London: SAGE Publications, Ltd., 2018. https://dx.doi.org/10.4135/9781526439284

Huang, Catalina Huamei, "Disillusionment and Disaggregation: Why Did Asian Americans Vote for Trump?" Master's Thesis, Claremont Mckenna College, 2017. https://scholarship.claremont.edu/cmc_theses/1514

Kandil, Caitlin Yoshiko. "Congressional Battleground Expands to Historically Conservative Little Saigon." NBC News. Last modified October 29, 2018. https:/www.nbcnews.com/news/asianamerica/congressional-battleground-expands-historically-conservative-little-saigon-n924311.

McLeod, S. (2019). Case Study Method. Case Study Method in Psychology. https://www.simplypsychology.org/case-study.html

Nakanishi, Don T. "Political Trends and Electorate Issues of the Asian Pacific American Population." America Becoming: Racial Trends and Their Consequences 1 (2001): 170-99.

Nichols, Henry James, Anthony Brown, and Boitumelo M. Diale. 2019. "School Involvement Expectations of Parents Who Accept and Embrace Their Child's Same Sex Sexual Orientation." Gender \& Behaviour 17 (4): 14287-95. http://search.ebscohost.com/login.aspx?direct=true\&db=asn\&AN=141403260\&site=ehostlive.

Nielsen. "How Asian American Media Consumption Could Be a Glimpse into the Future." Nielsen. Last modified May 24, 2017. https://www.nielsen.com/us/en/insights/article/2017/how-asianamerican-media-consumption-could-be-glimpse-into-future/.

Nguyen, Anh T. 2011. “The Vietnamese Population in the United States: 2010.” https://vacoc.org/wp-content/uploads/2018/05/The-Vietnamese-Population-2010_July-2.2011.pdf.

Noor, Khairul Baharein M. 2008. "Case Study: A Strategic Research Methodology.” American Journal of Applied Sciences 5, no. 11 (November): 1602-1604. https://doi.org/10.3844/ajassp.2008.1602.1604.

Satzewich, Victor. 2020. "Why some Vietnamese Americans support Donald Trump.” August 20, 2020. https://brighterworld.mcmaster.ca/articles/why-some-vietnamese-americans-support-donald-trump/.

Vu, Baoky. 2020. "The Asian American voters who could help Trump win a second term." https://www.cnn.com/2020/08/05/opinions/asian-american-vietnamese-trump-election-vu/index.html.

Yam, Kimmy. 2020. “Asian American voters support Biden at 54\% and Trump at 30\%, but numbers don't tell full story." https://www.nbcnews.com/news/asian-america/asian-american-voters-support-biden-54-trump-30numbers-don-n1240263. 


\section{Appendix}

\section{Appendix 1. Semi-Structured Qualitative Interview Questions in Vietnamese}

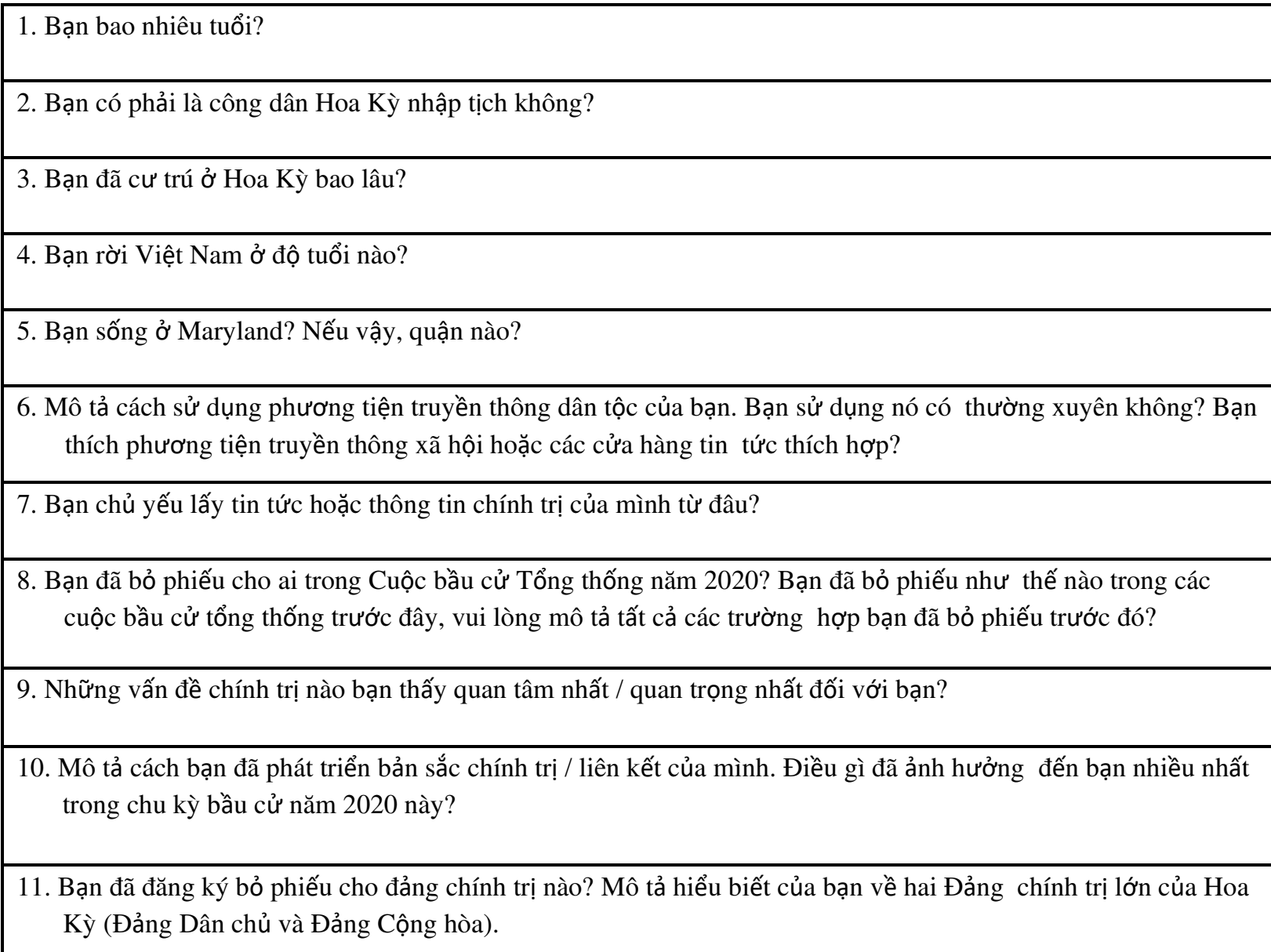

